\title{
Metastatic Transitional Cell Carcinoma
}

National Cancer Institute

\section{Source}

National Cancer Institute. Metastatic Transitional Cell Carcinoma. NCI Thesaurus. Code C129828.

A transitional cell carcinoma which has spread from the original site of growth to another anatomic site. 